\title{
Effect of Feeding Different Levels of Dietary Fiber on Productive and Economical Performance in Local Ducks: 1-During Growing Period and Subsequent Laying Performance Beshara, M. M.; Y. S. Rizk; A. M. El-Shhat; A. L. Awad and A. G. Abdallah Anim. Prod. Res. Institute, Agric. Res. Center, Minis. of Agric. Dokki, Giza Corresponding author: Malak Mansour; E-mail: malakman88@yahoo.com
}

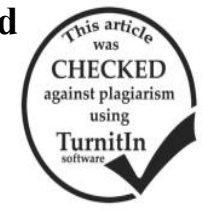

\begin{abstract}
This study was conducted to investigate effect of dietary different levels of crude fiber on productive performance and economic efficiency for growing Domiaty ducks from 6 to 18 weeks of age and subsequent effect during laying period. A total number of 117 local growing Domiaty ducks $(90++27$ ), 6 weeks old were weighed and divided into three dietary treatments on design as follow: control diet with $3.5 \%$ crude fiber while the other treatments were given higher levels of dietary crude fiber $(4.77$ and $6.23 \%)$ as a result of usage different levels of olive cake (OK). The results illustrated that dietary different levels of CF had no significant effect on body weight and body weight gain at the end of growing period. The same manner, no significant influence of dietary feed conversion ration. The diet included $6.23 \% \mathrm{CF}$ recorded significantly the highest value of ether extract digestibility, on the other hand, two levels of CF resulted in a significant improvement in digestibility of crude fiber (CF) as compared to the control diet. Ducks fed control diet recorded significantly lower value of organic matter (OM) digestibility than those received diet contained $4.77 \% \mathrm{CF}$. Nitrogen retention was significantly increased by the diet with 4.77 and $6.23 \% \mathrm{CF}$ compared to the control diet. The dietary different levels of CF lead to significantly higher HDL and ratio HDL/LDL than control. The ducks fed diet contained $4.77 \%$ CF reached to sexual maturity (SM) at earlier age (145 days) than control group by 8 days which reached to SM at 153 days. The diet with $4.77 \% \mathrm{CF}$ significantly improved egg number/duck as a subsequent effect compared to control diet. It is noted that total embryonic mortality was decreased as a result from the previous grower diet contained $4.77 \%$ CF by about $9.9 \%$ and there are improvement in hatchability of fertile eggs produced from ducks fed the same diet by about $2.26 \%$ compared to the control diet. It could be concluded that the grower Domiaty duck's diet which contained moderate levels of CF (4.77 and 6.23\%) did not have any harmful impact on productive performance and the diet with $4.77 \% \mathrm{CF}$ can be used to maximize productive, reproductive performance and economic efficiency as a subsequent impact during laying period.
\end{abstract}

Keywords: Ducks, Crude fiber, Olive cake, Growth performance, digestibility

\section{INTRODUCTION}

Poultry feeding consider a great challenge in intensive rearing systems, where it comprises from 65 to 70 of the production costs. Traditionally, dietary fiber has been considered to be anti nutritional factor in poultry diets because of its adverse influences upon palatability, voluntary energy intake, and the digestibility of nutrients (Sklan et al. 2003). Dietary fiber are components of plants which resistant to digestion by endogenous enzymes and consists of nondigestible carbohydrates and lignin. However, scientific publications reported that the adding of appropriate levels of insoluble fiber in diets of poultry might benefit the development of gizzard and small intestine (Svihus, 2011), the production of hydrochloric acid and enzymes of small intestine (Gonzalez-Alvarado et al. 2008), the digestibility of non - fiber nutrients, and the gastrointestinal refluxes (Jimenez-Moreno et al., 2011).

Mateos et al. (2012) mentioned that the benefits due to adding the crude fiber in the bird's diets on the growth performance probably due to improving nutrients digestibility results from a better development and function of the gizzard rather than from changes in the pathways of metabolic. In addition, these beneficial effects ultimately might result in improved gastrointestinal tract health (Yokhana et al., 2016). According to studies performed in recent years, it has been illustrated that the appropriate levels of different fiber sources in the diet improves development of digestive organ (Hetland and Svihus, 2007) and increases hydrochloric acid, bile acids, and enzyme secretion (Svihus, 2011). These changes might result in improvements in nutrient digestibility (Amerah et al.,
2009), growth performance (González-Alvarado 2010), gastrointestinal tract health (Perez et al., 2011), and eventually, animal welfare (Van Krimpen et al., 2009). Varastegani and Dahlan, (2014) illustrated that utilization of crude fiber in the poultry diet as a supplement play an important role in poultry health as well as poultry production. However, the effects due to fiber inclusion depend on the source, amount of dietary fiber and the characteristics of the diet as well as on the physiological status and health of the bird as well as on the ingredients which included in basal diet (Amerah et al. 2009).

Olive cake $(\mathrm{OK})$ is the raw material (seed fractions) resulting from extraction of olive oil and the residual seeds from the industry of olive fruit reserve after mash the seed fractions where it included nearly $30 \%$ from the seeds, due to low nutritive value (low in energy, digestible proteins and minerals and high in lignin), OK is seldom integrated into poultry feeding. However, OK is considered as a good source of fat (18\% crude fat), for its level of residual oil, this can constitute a complementary energy source. The utilization of by-products as animal feed is undoubtedly a good way of recycling these waste products (Sadeghilet al., 2009). Thus, the aim of current study was to investigate the effects of dietary inclusion of different amounts of fiber (4.77 and 6.23\%) as a result of usage 5 and 10 of $\mathrm{OK}$ in the grower diet on performance of the Domiaty ducks during the growing period from 6-18 weeks of age and the subsequent effect during the laying period. 


\section{MATERIALS AND METHODS}

The current research was performed at El-Serw water fowl research station, Animal Research Institute, Agriculture Research Center, Ministry of Agriculture, Egypt. One hundred and seventeen local growing Domiaty ducks $(90++27 \precsim), 6$ weeks old were weighed and divided into three dietary treatments, birds were weighed and assigned to treatments based on body weight and it were kept on deep litter, in an open-sided, naturally ventilated growing house and exposed to natural day length. The body weight, body weight gain and feed conversion ratio of each group were measured every 28 days.the mean feed intake durinj the growing period was nearly $90 \mathrm{~g} / \mathrm{duck} / \mathrm{day}$. In the end of growing period the average body weight was calculated for each dietary treatment then the adjusted number of ducks (27 $q+9 \hat{\jmath}$ ) for each dietary treatment was continued in the same house and all treatments were fed on the same layer diet to evaluate the effect of previous dietary treatments on sexual maturity and productive performance till 36 weeks of age.

Chemical analysis of olive cake and experimental diets:

Samples of olive cake (part of pulp, seeds and embryo which include $30 \%$ of olive seeds) were taken to determine approximate analysis according to AOAC (1990) method. Acid detergent fiber (ADF) and neutral detergent fiber (NDF) were determined by Van Soest et al. (1991). Nitrogen free extract (NFE) was calculated by subtracting the sum of protein, ether extract, NDF from organic mater $(\mathrm{OM})$ and the hemicelluloses content was calculated as a difference between ADF and ADF. The metabolizable energy (ME) of $\mathrm{OK}$ was calculated based on chemical composition according to equation NRC (1994) where: $\mathrm{ME}=36.63 \times \mathrm{CP}+77.96 \times$ $\mathrm{EE}+19.87 \times \mathrm{NFE}$.

The approximate analysis of olive cake (OK) used in this study is presented in Table (1). The ingredients and the nutrient composition of the experimental diets are presented in Table (2).

Table 1. Chemical composition of Olive cake (OK) (Abdallah et al., 2016).

\begin{tabular}{lc}
\hline Nutrients (\%) & $\begin{array}{c}\text { As fed basis } \\
\text { OK }\end{array}$ \\
\hline Moisture & 6.16 \\
Dry Mater & 93.84 \\
Crude Protein & 6.79 \\
Crude Fat & 18.92 \\
Crude Fiber & 33.32 \\
Neutral detergent fiber (NDF) & 57.00 \\
Acid detergent fiber (ADF) & 41.65 \\
Cellulose & 27.85 \\
Hemicellulose & 15.35 \\
Lignin & 13.80 \\
Ash & 10.92 \\
ME (kcal/kg) * & 1728 \\
\hline * Metabolizable energy (ME, $\mathbf{~ k c a l / k g ) ~} \mathbf{w a s}$ calculated according to \\
NRC (1994). ME $=\mathbf{3 6 . 6 3} \times \mathbf{C P}+\mathbf{7 7 . 9 7} \times \mathbf{E E}+\mathbf{1 9 . 8 7} \times \mathbf{~ N F E}$.
\end{tabular}

In the duck grower diets, three experimental diets were formulated to nearly meet the NRC 1994 recommendations and all diets were isocaloric and isonitrogenous but it contained gradually levels of the crude fiber. The ducks were fed a basal diet contained $3.65 \% \mathrm{CF}$ and the remaining dietary treatments were given higher levels of fibers (4.77 and 6.23\%) as a result of usage different levels of olive cake (5 and $10 \%)$.

Table 2. Composition and calculated of the experimental diets fed to local Domiaty ducks throughout the growing period (6-18 weeks of age).

\begin{tabular}{|c|c|c|c|}
\hline \multirow[b]{3}{*}{ Ingredients (\%) } & \multicolumn{3}{|c|}{ Dietary fiber level, \% } \\
\hline & 3.65 & 4.77 & 6.23 \\
\hline & $\begin{array}{c}1 \\
\text { (control) }\end{array}$ & 2 & 3 \\
\hline Yellow corn & 71.35 & 70.85 & 65.85 \\
\hline Soy bean meal (44 \%) & 18.50 & 19.70 & 18.50 \\
\hline Corn gluten $(60 \%)$ & 0.00 & 0.00 & 1.00 \\
\hline Wheat bran & 6.00 & 0.30 & 0.50 \\
\hline Olive cake $(6.79 \%)$ & 0.00 & 5.00 & 10.00 \\
\hline Di-calcium phosphate & 1.35 & 1.35 & 1.35 \\
\hline Limestone & 2.00 & 2.00 & 2.00 \\
\hline Vit \& Min. premix ${ }^{1}$ & 0.30 & 0.30 & 0.30 \\
\hline $\mathrm{NaCl}$ & 0.30 & 0.30 & 0.30 \\
\hline DL- Methionine (99\%) & 0.05 & 0.05 & 0.05 \\
\hline Sodium bicarbonate & 0.15 & 0.15 & 0.15 \\
\hline Total & 100 & 100 & 100 \\
\hline Calculated Analysis ${ }^{2}$ & & & \\
\hline Crude protein $\%$ & 14.57 & 14.55 & 14.62 \\
\hline ME ( Kcal / kg ) & 2888 & 2909 & 2842 \\
\hline Crude fiber $\%$ & 3.65 & 4.77 & 6.23 \\
\hline Ether extract \% & 3.00 & 3.95 & 4.72 \\
\hline Calcium (\%) & 1.14 & 1.14 & 1.13 \\
\hline Av. Phosphorus (\%) & 0.385 & 0.368 & 0.36 \\
\hline Methionine \% & 0.33 & 0.319 & 0.319 \\
\hline Meth + Cyst \% & 0.583 & 0.573 & 0.578 \\
\hline Price $(\mathrm{LE} / \mathrm{kg})^{3}$ & 4.17 & 4.08 & 3.96 \\
\hline
\end{tabular}

1-Each $3 \mathrm{~kg}$ of Vit .and Min. premix contains 100 million IUVit A;2 million IU Vit.D3;10 g Vit.E; 1 g Vit.K3 ; 1 g Vit B1; 5 g Vit $B 2 ; 10 \mathrm{mg}$ Vit.B12 ; $1.5 \mathrm{~g}$ Vit B6; $30 \mathrm{~g}$ Niacin ;10 g Pantothenic acid ;1g Folic acid;50 mg Biotin ; 300 g Choline chloride; $50 \mathrm{~g}$ Zinc; $4 \mathrm{~g}$ Copper; $0.3 \mathrm{~g}$ Iodine ; $30 \mathrm{~g}$ Iron; $0.1 \mathrm{~g}$ Selenium; 60g Manganese ;0.1 g Cobalt; and carrier $\mathrm{CaCO3}$ to $3000 \mathrm{~g}$.

2-According to Feed Composition Tables for animal and poultry feedstuffs used in Egypt (2001).

3-Price of one $\mathrm{kg}$ (LE) at time of experiment for different ingredients : yellow corn, 3.95; Soy been meal, 5.2; Corn gluten, 7.0; Wheat bran, 2.1; Olive cake, , 3.5; Di-calcium, 4.8; limestone, 0.2; Vitamins and minerals, 27.0; $\mathrm{Na}$ cl, 0.50; Sodium bicarbonate.4.0; Methionine, 99.0 and Sodium bicarbonate, 4 .

\section{Slaughter test:}

At the end of 18 weeks of age, three ducklings/ treatment were taken and slaughtered. The relative weight of proventriculus, gizzard, abdominal fat and relative length of small intestine and ceca were determined. The weight of proventriculus, gizzard and abdominal fat were expressed relative to their body weight. The lengths of small intestine and ceca were also measured per $100 \mathrm{~g}$ of the body weight. Blood samples were collected without anticoagulant and kept at room temperature then the tubes were centrifuged at $3500 \mathrm{rpm}$ for 20 minutes to separate clear serum, afterward blood serum was used to determine serum 
triglycerides, total cholesterol LDL and HDL by using commercial kits.

Nutrients digestibility and nitrogen retention:

At 18 weeks of age one male per each replicate was selected on the basis of the average body weight. Birds were individually housed in metabolic cages $(60$ $\mathrm{cm}$ long. $50 \mathrm{~cm}$ wide. $60 \mathrm{~cm}$ high) and fed their respective experimental diets (Table 2), the adaptation period was two days. The excreta were quantitatively collected for three days, feed consumption data were recorded. The excreta were dried in a forced oven at 65 ${ }^{\circ} \mathrm{C}$ for 48 hours. Finally, the excreta were ground well and stored in plastic bags. The proximate analysis of experimental diet and the excreta were carried out according to the official methods (A.O.A.C., 1990). Digestion coefficients calculated according to the equation:

Digestion coefficient $\%=[($ Nutrient consumption $(g)-$ Fecal nutrient content (g)) / Nutrient consumption (g)] x 100 .

Nitrogen retention (NR) was calculated from the following formula, $\mathrm{NR}=(\mathrm{N}$ content of dry matter of dry feed $-\mathrm{N}$ content of dried excreta) x $100 / \mathrm{N}$ content of dry feed.

During the laying period:

Body weight at the sexual maturity, body weight at 36 weeks, egg number, average egg weight, egg mass and feed consumption through the experimental periods were recorded as well egg production performance and feed conversion ratio were calculated through the same periods, also body weight change were calculated through the whole experimental period. In addition, the reproduction traits which included fertility, commercial and scientific hatchability were measured.

\section{Economic efficiency:}

At the end of the research (36 wk), economical efficiency for egg production was calculated using the following equation:

Economic efficiency $(\%)=($ Net return LE/Total feed cost LE) $\times 100$. Where net return=Total return-the cost of feeding Statistical analysis:

Data were statistically analyzed using General Linear Models Procedure of the SPSS program (2008). Differences means among treatments were subjected to Duncan' s Multiple Range- test (Duncan, 1955). The following model was used to study the effect of treatments on the parameters investigated as follows: $\mathrm{Yij}=\mu+\mathrm{Ti}+$ eij $\quad$ where:

Yij $=$ an observation, $\mu=$ overall mean, $\mathrm{Ti}=$ effect of treatment $(\mathrm{i}=1,2,3)$ and

eij $=$ Random error.

\section{RESULTS AND DISCUSSION}

\section{Chemical analysis of $\mathrm{OK}$ :}

Results of proximate analysis of olive cake (OK) are presented in Table (1).Crude protein (CP), ether extract (EE), crude fiber (CF) and lignin content $\mathrm{OK}$ are noticeable where CP was 6.79 while EE was 18.92 and 1.26 in $\mathrm{OK}$, also, the records of $\mathrm{CF}$ and lignin were 33.32 and $13.8 \%$ in $\mathrm{OK}$ respectively.
Table 3. Ingredients and calculated analysis of the basal layer diets fed to local Domiaty ducks throughout the experiment $(24-36$ wks)

\begin{tabular}{|c|c|}
\hline Ingredients (\%) & Layer $(24-36$ wks $)$ \\
\hline Yellow corn & 62.75 \\
\hline Soy bean meal (44 \%) & 19.75 \\
\hline Gluten $(60 \%)$ & 4.27 \\
\hline Wheat bran & 3.00 \\
\hline Di-calcium phosphate & 1.39 \\
\hline Limestone & 8.16 \\
\hline premix $^{1}$ & 0.30 \\
\hline $\mathrm{NaCl}$ & 0.37 \\
\hline DL- Methionine (99\%) & 0.01 \\
\hline Total & 100 \\
\hline Calculated Analysis ${ }^{2}$ & \\
\hline Crude protein \% & 16.53 \\
\hline ME ( Kcal / kg ) & 2756 \\
\hline Crude fiber $\%$ & 3.30 \\
\hline Ether extract \% & 2.99 \\
\hline Calcium (\%) & 3.51 \\
\hline Av. Phosphorus (\%) & 0.38 \\
\hline Methionine $\%$ & 0.31 \\
\hline Methio + Cyst \% & 0.61 \\
\hline Price $(\mathrm{LE} / \mathrm{kg})^{3}$ & 4.05 \\
\hline
\end{tabular}

1- Each $3 \mathrm{~kg}$ of Vit and Min. premix contains 100 million IUVit A;2 million IU Vit.D3;10 g Vit.E; 1 g Vit.K ${ }_{3} ; 1$ g Vit B1; 5 g Vit B2 ;10 mg Vit.B12 ; $1.5 \mathrm{~g}$ Vit B6; $30 \mathrm{~g}$ Niacin ;10 g Pantothenic acid ; $1 \mathrm{~g}$ Folic acid;50 mg Biotin ; $300 \mathrm{~g}$ Choline chloride; $50 \mathrm{~g}$ Zinc; $4 \mathrm{~g}$ Copper; $0.3 \mathrm{~g}$ Iodine ; $30 \mathrm{~g}$ Iron; $0.1 \mathrm{~g}$ Selenium; $60 \mathrm{~g}$ Manganese ;0.1 g Cobalt; and carrier $\mathrm{CaCO}_{3}$ to $3000 \mathrm{~g}$.

2- According to Feed Composition Tables for animal and poultry feedstuffs used in Egypt (2001).

3- Price of one $\mathrm{kg}$ (LE) at time of experiment for different ingredients : yellow corn , 3.95; Soy bean meal, 5.2; Wheat bran, 2.2; Di-calcium, 4.8; limestone, 0.2 ; Vit and min.,27.0 ; Nacl,0.50; Meth., 99.0.

\section{Growth performance traits:}

The growth performance parameters of growing Domiaty ducks fed diets contained different levels of crude fiber (CF) from 6 to 18 weeks of age are shown in Table (4). Results observed that no significant influence in body weight (BW) and body weight gain (BWG) could be detected among all dietary treatments compared to the control diet.

Feed intake and feed conversion ratio:

The daily feed intake (FI) and feed conversion ratio (FC) of growing ducks fed diets with different levels of CF from 6 to 18 weeks of age are shown in Table (4). Average daily feed intake was not affected by the dietary CF applied irrespective of the fluctuations observed where the results in table 4 indicated that no significant influence due to dietary different levels of $\mathrm{CF}$ on feed intake during the collective period (6-18 weeks of age). The results of FI were logically where it consist with the results of relative weight of gizzard and length of small intestine (Table 6) where the results illustrated that no significant influence on relative weight of gizzard and small intestine where the digesta retention time or the volume of gastrointestinal tract seem to be the most likely explanation for feed intake. In addition, level and type of fiber is the essential 
factors in regulation the feed intake and mean retention time in the cecum (De Blas et al., 1999).

Table 4. Effect of feeding different levels of dietary crude fiber during growing period on growth performance of local Domiaty ducks (6-18 weeks of age)

\begin{tabular}{|c|c|c|c|c|}
\hline \multirow{2}{*}{ Age (wks) } & \multicolumn{3}{|c|}{ Dietary fiber level, $\%$} & \multirow[t]{2}{*}{$\begin{array}{c}\text { Pooled } \\
\text { SEM }\end{array}$} \\
\hline & 3.65 & 4.77 & 6.23 & \\
\hline \multicolumn{5}{|c|}{ Body weight (g/ duckling) } \\
\hline 6 & 578.0 & 579.0 & 574.0 & 2.48 \\
\hline 10 & 1236.7 & 1219.3 & 1239.5 & 13.09 \\
\hline 14 & 1608.9 & 1614.2 & 1605.4 & 17.04 \\
\hline 18 & 1876.7 & 1854.0 & 1839.3 & 13.57 \\
\hline \multicolumn{5}{|c|}{ Body weight gain (g/ duckling/ 28 days) } \\
\hline $6-10$ & 658.7 & 640.3 & 665.5 & 13.03 \\
\hline $10-14$ & 372.3 & 394.9 & 36 & 21.49 \\
\hline $14-18$ & 267.7 & 239.8 & 234.0 & 18.35 \\
\hline $6-18$ & 1298.7 & 1275.0 & 1265.3 & 14.17 \\
\hline \multicolumn{5}{|c|}{ Feed intake ( $\mathrm{g} /$ duckling/ 28 days) } \\
\hline $6-10$ & 2172.6 & 2119.9 & 2146.8 & 25.66 \\
\hline $10-14$ & 2531.5 & 2495.5 & 2413.0 & 36.25 \\
\hline $14-18$ & 2712.3 & 2808.9 & 2853.0 & 35.72 \\
\hline $6-18$ & 7416.4 & 7424.3 & 7412.8 & 67.53 \\
\hline \multicolumn{5}{|c|}{ Feed conversion ratio (g. feed $/ \mathrm{g}$ BW gain) } \\
\hline $6-10$ & $3.30^{\circ}$ & 3.34 & 3.23 & 0.09 \\
\hline $10-14$ & 6.83 & 6.51 & 6.79 & 0.34 \\
\hline $14-18$ & 10.53 & 12.15 & 12.81 & 0.93 \\
\hline $6-18$ & 5.71 & 5.83 & 5.86 & 0.73 \\
\hline
\end{tabular}

As for feed conversion ratio, it is clearly observed that dietary treatments did not any significant alternations compared to the control diet $(3.65 \% \mathrm{CF})$ through the intervals periods of study, and overall period However, it could be mentioned that all dietary treatments resulted in decrease in feed cost especially the diet contained $6.23 \% \mathrm{CF}$.

The most interesting result that there was no any adverse effect on growth performance of Domiaty ducks during the period from 6 to 18 weeks of age; these results are in the line with the findings of the study by Abbas (1992) who found that $7 \%$ CF level had no adverse impact on the body weight gain and feed intake of Arbor Acres from 6 to 8 weeks of age. In addition, the results in current study showed that a moderate amount of CF could be used in ducks diet during grower period without any deleterious effect on bird's performance. These results agree with Abd El-latif (2000) who elucidated that BW and BWG were not significantly affected by feeding Pekin ducks on diets included CF levels up to $12 \%$ during the entire tested period from 2 to 8 weeks of age. According to Hetland and Svihus, (2001), BWG do not influence when the diets containing high levels of insoluble fiber where the birds able to maintain adequate with presence high levels from crude fiber. This effect may be attributed to fiber increases the rate of passage of the digesta through the digestive system as well as the physical capacity of the gastrointestinal tract. As a rule feed intake/day did not significantly effect by treatments, this impact may be due to the digesta retention time or the volume of gastrointestinal tract seem to be the most likely explanations for feed consumption thus the results of

relative weight of gizzard and relative length of small intestine as shown in Table 6 may be the likely reason for this effect.

In addition, this influence might due to the ratio between the insoluble and soluble fiber, where this ratio appears to be important in the diets formation to provide optimal productive performance (Burhalter et al., 2001). Also according to Hetland et al. (2005) and Hetland and Svihus (2007) there are a beneficial effects of fiber inclusion in the diet of pullets and in laying hens. This effect due to inclusion of a crude fiber in the grower diet might result in improvement in digestibility of $\mathrm{CF}, \mathrm{OM}$ and NR as shown in Table (5), also this effect probably due to the improvement in lipid metabolism by the increase CF in the grower diet (Table 7) and eventually, animal welfare. Increasing the insoluble fiber content of the diet has resulted in an increased gizzard weight and gizzard contents (González-Alvarado et al., 2007 ; Amerah et al., 2009), and, generally, there are improve in functioning of the gastrointestinal tract (Svihus, 2011).

Table 5. Effect of feeding different levels of dietary crude fiber during the growing period on digestibility coefficient, ash and nitrogen retention of local Domiaty ducklings at 18 weeks of age

\begin{tabular}{lcccc}
\hline Parameters & \multicolumn{3}{c}{ Dietary fiber level, \% } & Pooled \\
Digestibility coefficient \% & $\mathbf{3 . 6 5}$ & $\mathbf{4 . 7 7}$ & $\mathbf{6 . 2 3}$ & MSE \\
\hline Dry matter & 73.60 & 77.41 & 74.61 & 2.72 \\
Ether extract & $89.13^{\mathrm{b}}$ & $82.48^{\mathrm{c}}$ & $95.05^{\mathrm{a}}$ & 5.52 \\
Crude fiber & $22.00^{\mathrm{b}}$ & $45.91^{\mathrm{a}}$ & $47.95^{\mathrm{a}}$ & 13.33 \\
Organic m. & $74.66^{\mathrm{b}}$ & $78.78^{\mathrm{a}}$ & $76.36^{\mathrm{ab}}$ & 2.70 \\
Ash and nitrogen retention & & & \\
Ash retention (\%) & $63.10^{\mathrm{a}}$ & $63.05^{\mathrm{a}}$ & $56.11^{\mathrm{b}}$ & 4.85 \\
$\mathrm{~N}$ intake (g/d) & 3.28 & 3.20 & 3.44 & 0.45 \\
$\mathrm{~N}$ excreta (g/d) & 1.39 & 1.16 & 1.32 & 0.17 \\
N retention (\%) & 57.23 & 63.65 & 61.17 & 4.45 \\
\hline
\end{tabular}

a,b,c,.. : means in the same row bearing different superscripts are significantly different $(p \leq 0.05)$.

Table 6. Effect of feeding different levels of dietary crude fiber during the growing period on relative weight proventriculus, gizzard, relative length of small intestine and ceca for local Domiaty ducks at 18 weeks of age.

\begin{tabular}{|c|c|c|c|c|c|}
\hline \multirow{2}{*}{\multicolumn{2}{|c|}{ Items }} & \multicolumn{3}{|c|}{ Dietary fiber level, \% } & \multirow{2}{*}{$\begin{array}{c}\text { Pooled } \\
\text { MSE }\end{array}$} \\
\hline & & 3.65 & 4.77 & 6.23 & \\
\hline \multicolumn{2}{|l|}{ LBW (g) } & 1890.0 & 1883.3 & 1908.3 & \multirow{3}{*}{1.70} \\
\hline \multirow{2}{*}{\multicolumn{2}{|c|}{$\begin{array}{l}\text { Carcass } \% \\
\text { Parameters } \%\end{array}$}} & 70.95 & 69.36 & 70.31 & \\
\hline & & & & & \\
\hline \multicolumn{2}{|c|}{ Liver } & $1.86^{\mathrm{a}}$ & $1.54^{\mathrm{b}}$ & $1.71^{\mathrm{ab}}$ & 0.07 \\
\hline \multicolumn{2}{|l|}{ Heart } & 0.81 & 0.74 & 0.72 & 0.05 \\
\hline \multicolumn{2}{|l|}{ Gizzard } & 2.97 & 3.17 & 3.26 & 0.19 \\
\hline \multicolumn{2}{|c|}{ T. edibles } & 5.64 & 5.45 & 5.68 & 0.66 \\
\hline \multicolumn{2}{|c|}{ Gizzard vo. } & 2.83 & 3.03 & 3.05 & 0.18 \\
\hline \multirow{4}{*}{ 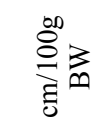 } & Duod. & 1.54 & 1.44 & 1.52 & 0.07 \\
\hline & Jej. & 3.70 & 4.24 & 3.62 & 0.02 \\
\hline & Ileum & 3.64 & 3.72 & 3.60 & 0.14 \\
\hline & Ceca & 1.44 & 1.59 & 1.56 & 0.07 \\
\hline \multicolumn{2}{|c|}{ Abdominal Fat } & 1.27 & 0.77 & 0.73 & 0.14 \\
\hline
\end{tabular}




\section{Nutrients digestibility:}

The data in Table (5) showed that all dietary treatments used in this study did not significantly differ from control diet in digestibility of dry matter (DM), but in respect of ether extract digestibility (EE), the diet included $6.23 \%$ CF $(10 \%$ OK) recorded significantly the highest value compared to the control diet. On the other hand, the different levels of CF (4.77 and $6.23 \% \mathrm{CF}$ ) resulted in a significant improvement in digestibility of crude fiber (CF) as compared to the control diet. In addition, results obtained clearly observed that the ducks fed control diet recorded significantly lower value of organic matter (OM) digestibility than those received diet contained $4.77 \% \mathrm{CF}$.

Regarding ash retention, the results showed that ash retention \% did not significantly influence due to the different levels of $\mathrm{CF}$ in the grower diet for Domiaty ducks. However, the diet contained $6.23 \%$ CF gave significantly lower value of ash retention \% than control diet. Also, it could be mentioned that irrespective of nitrogen either intake or excretion and nitrogen retention (NR) was insignificantly affected by different dietary treatments, but the diet included moderate amount of CF (4.77\%) results from using 5\% OK gave the best value of NR by about $11.2 \%$ as compared to control diet.

The improvement in EE digestibility results from the diet with $6.23 \%$ CF probably due to the olive oil in OK where Stark and Mader (2002) reported that olive oil is a good source of photochemical compounds and vitamin $\mathrm{E}$. Mailer (2006) found that olive oil contains hydrocarbons such as chlorophyll and carotenoids and $\beta$-carotene which acts as an antioxidant during storage. Servili et al. (2014) illustrated that the nutritional value of olive oil is due to the high monounsaturated fatty acid content, principally made of oleic acid. Hydrophilic and lipophilic phenols represented the main antioxidants of olive oil.

The improvement in digestion coefficient of crude fiber due to the grower's diets for ducks contained 4.77 and $6.23 \%$ CF perhaps due to CF related enzyme groups are secreted by microorganisms in the caecum where Hsu et al., (2000) reported that goslings fed the high fiber diets had higher cellulose activities than those fed low fiber diets and this might be due to high fiber-fed groups possessing higher numbers of microorganisms in the caecum. In respect of NR the results illustrated that it was significantly increased by the diet with 4.77 and $6.23 \% \mathrm{CF}(5 \% \mathrm{OK}$ and $10 \% \mathrm{OK}$ ) compared to the control diet, this effect was expected to result in lower $\mathrm{NH} 3$ emission according to the results was found by Liang et al., (2005). Therefore, increasing the dietary crude fiber content may be a feasible option to mitigate $\mathrm{NH} 3$ emission in a growing ducks (Roberts et al., 2007).

Relative weight of segments of gastrointestinal tract (GIT):

Results of relative weight of gizzard and other segments of gastrointestinal tract are shown in Table (6). No statistical significant influence on all carcass traits which included relative weight of carcass, heart, gizzard, total edibles, gizzard volume and relative length of small intestine and ceca could be detected due to the dietary different levels of $\mathrm{CF}$ except for the liver \% where the diet with $4.77 \%$ CF tend to significantly lower liver $\%$ than the control diet. However, the relative weight of gizzard and relative length of caecum were insignificantly increased where it reached about from 6.73 to $9.76 \%$ and from 10.42 to $8.33 \%$ respectively higher than control diet. Also insignificant decrement was observed in abdominal fat due to the different levels of CF compared to the control diet implying that dietary CF positively affected the fat deposition in ducks.

These results are consistent with Siregar et al. (1982) who mentioned that when using increase amounts of dietary fiber in the diets of Pekin ducklings, fat content in the carcass was reduced. Jorgensen et al. (1996) illustrated that increase of the insoluble fiber content in the diet often results in a decrease in carcass yield in broiler chickens. But, Gonzalez-Alvarado et al. (2010) mentioned that inclusion of oat hulls did not affect the yield of valuable parts. The present findings are agreement with Victor et al., (2013) who reported that the mean effects of feeding diet with or without insoluble raw fiber concentrate on the relative weights of sections of the gastrointestinal tract (GIT) and accessory organs as well size of some segments of the GIT were no significant differences between the treatments in any of the parameters. Yokhana et al. (2016) illustrated that in 19-week-old hens the relative weights of the small intestine were raised but it was not changed in 8-week-old pullets by the dietary inclusion of insoluble fiber. Birds adapt quickly to alterations in the dietary crude fiber content by the modifications of the length and weight of the gizzard, small intestine and the rate of passage through the diverse sections of the gastrointestinal tract (Mateos et al. 2012). Increasing amount of insoluble fiber in the diet resulted in a decreased length of the small intestine (Sklan et al. 2003), along with an increased relative weights of proventriculus and gizzard (Jimenez-Moreno et al. 2011 ; Yokhana et al. 2016).

\section{Serum biochemical:}

Serum biochemical parameters were within normal range for growing ducks at 18 weeks of age fed different levels of CF as shown in Table (7).Statistical analysis for data revaluated that the values of serum total cholesterol were slightly significantly higher for duck's serum fed different levels of CF than for those fed the control diet. However, it is worth to mention that the different levels of CF lead to significantly higher HDL and ratio HDL/LDL than control; meanwhile in case of LDL the opposite was true. On the other hand, when the diets contained $6.23 \%$ CF was applied the triglycerides were significantly decrease while no significant influence in serum triglycerides due to the diet with $4.77 \% \mathrm{CF}$ compared to the control diet.

According to Wang et al., (2017), low-density lipoprotein (LDL) can transport their content of lipid molecules into artery walls, attract macrophages, and thus drive atherosclerosis thus LDL is sometimes called bad cholesterol. Conversely, high-density lipoprotein (HDL) is often referred to as healthy cholesterol 
because high-density lipoprotein particles can remove lipid molecules from macrophages in the wall of arteries. It has been reported that dietary crude fiber reduces LDL and increase HDL in blood because fiber intervenes with reabsorption of lipids and cholesterol by absorbing bile acid and cholesterol, consequently disarranging the lipid metabolism.

Table 7. Effect of feeding different levels of dietary crude fiber during the growing period on digestibility coefficient of nutrients of local Domiaty ducklings at 18 weeks of age

\begin{tabular}{|c|c|c|c|c|}
\hline \multirow{2}{*}{ Parameters } & \multicolumn{3}{|c|}{ Dietary fiber level, \% } & \multirow[t]{2}{*}{$\begin{array}{l}\text { Pooled } \\
\text { MSE }\end{array}$} \\
\hline & 3.65 & 4.77 & 6.23 & \\
\hline T. cholesterol(g/dl) & $241.5^{\circ}$ & $253.5^{\circ}$ & $272.5^{\mathrm{a}}$ & 5.14 \\
\hline $\mathrm{HDL}(\mathrm{g} / \mathrm{dl})$ & $43.9^{\mathrm{b}}$ & $71.5^{\mathrm{a}}$ & $76.6^{\mathrm{a}}$ & 5.30 \\
\hline LDL $(\mathrm{g} / \mathrm{dl})$ & $102.1^{\mathrm{a}}$ & $55.8^{\mathrm{c}}$ & $75.9^{\mathrm{b}}$ & 6.76 \\
\hline HDL/LDL & $0.43^{\mathrm{c}}$ & $1.28^{\mathrm{a}}$ & $1.01^{\mathrm{b}}$ & 0.13 \\
\hline Triglycerides & $303.0^{\mathrm{a}}$ & $281.0^{\mathrm{ab}}$ & $250.5^{\mathrm{b}}$ & 9.30 \\
\hline
\end{tabular}

$a, b$ : means in the same row bearing different superscripts are significantly different $(p \leq 0.05)$

\section{Sexual maturity:}

Results in Table (8) showed that the age of sexual maturity (SM) was not significantly affected by the different levels of CF. However, the ducks fed diet contained $4.77 \% \mathrm{CF}$ reached to SM at earlier age (145 days) than control group by 8 days where ducks fed control diet reached to SM at 153 days. In respect of $1^{\text {st }}$ egg weight $(\mathrm{g})$, results showed that there are a no significant differences among treatments and control diet but the ducks which reached to SM early had the lowest $1^{\text {st }}$ egg weight. Pottguter (2009) reported that during the growing period of poultry, the dietary fiber is a key importance to the sexual mature.

In addition, inclusion CF in grower duck's diet up to $6.23 \%$ resulted in insignificant decrease in initial body weight at SM and body weight at 36 weeks of age compared to control diet. Also, it is evident to note that no significant alternations in change body weight due to the different levels of $\mathrm{CF}$ in grower diets compared to control diet.

Table 8. Effect of feeding different levels of dietary crude fiber during growing period on age at sexual maturity (SM), live body weight, change of body weight and viability percentage

\begin{tabular}{|c|c|c|c|c|}
\hline \multirow{2}{*}{ Criteria } & \multicolumn{3}{|c|}{ Dietary fiber level, \% } & \multirow[t]{2}{*}{$\begin{array}{c}\text { Pooled } \\
\text { MSE }\end{array}$} \\
\hline & 3.65 & 4.77 & 6.23 & \\
\hline$\overline{\text { SM (days) * }}$ & $153^{\mathrm{a}}$ & $145^{b}$ & $151^{\mathrm{ab}}$ & 1.57 \\
\hline $1^{\text {st }}$ egg weight, $g$ & $57.6^{\mathrm{a}}$ & $51.4^{\mathrm{b}}$ & $52.4^{\mathrm{ab}}$ & 1.25 \\
\hline Initial LBW, g (At SM) & 2005.0 & 1964.7 & 1973.2 & 14.68 \\
\hline Final LBW, g (36 wk) & 2173.7 & 2094.4 & 2074.5 & 23.56 \\
\hline Change body weight $(\mathrm{g})$ & 169 & 130 & 101 & 16.3 \\
\hline
\end{tabular}

Subsequent effect to dietary fiber on laying performance:

Results in Table 9 clearly observed that the grower diets which contained $4.77 \% \quad \mathrm{CF}$ had significantly lower egg number/bird as a subsequent effect during the first period (24-28 weeks of age) than control diet. On the other hand, during the second period ducks fed previous grower diet contained dietary treatments did not actually differ from control diet. Also, ducks fed $4.77 \% \mathrm{CF}$ produce significantly the greatest egg number/bird compared to control diet and other treatment during the period from 32 to 36 weeks of age. It could be mentioned that irrespective of the previous fluctuations observed, superiority of the diet contained $4.77 \% \mathrm{CF}$ at egg number /bird as it was significantly higher than control through the collective period (24-36 weeks of age).

As for egg weight, the most remarkable result during the overall period is that the most dietary treatment with $6.23 \% \mathrm{CF}$ produced significantly smaller egg weight than those produced by ducks fed the previous control diet but, no significant effect due to the previous diets contained $4.77 \% \mathrm{CF}$ on egg weight compared to the control diet. Generally regarding egg mass values, results showed that ducks fed previous grower diet contained moderate amount of CF $(4.77 \%)$ produced egg mass significantly better as compared to the control diet. In fact, the diet included 4.77\% CF (5\% $\mathrm{OK})$ during growing period returned to occupy the first position in egg mass and significantly exceeded the control and other dietary treatment as a subsequent influence during the laying period. These results were may be associated with the previous results in the current study during the growing period where there are improvement in digestibility of $\mathrm{EE}, \mathrm{CF}, \mathrm{OM}$ and NR (Table 5) gizzard weigh, relative cecum length (Table 6) and eventually ducks welfare (Kalmendal et al., 2011). Improved feed use is at least partly resulted from increase digestibility of starch and may be due to increase the activity of gizzard (Hetland et al., 2005). Also, the gizzard governs many physiological aspects of gastrointestinal tract including: 1) particle size reduction; 2) motility regulation; 3) control of feed flow and gastro duodenal refluxes and 4) improvement of digestive secretions, including hydrochloric acid, and endogenous enzymes, all these influences affect on functioning of the gastrointestinal tract (Mateos et al., 2012).

Also, Mateos et al., (2012) reported that the amounts of fiber required depends on the descriptions of fiber source, especially its solubility and lignin content, and the birds require a moderate level of crude fiber in the diet for maximum productive performance.

In addition, results in Table 9 illustrated that all dietary different levels of CF had no significant effect on feed intake / duck/day through the intervals and collective laying periods except for the third period where feed intake was significantly decreased in the ducks fed previous grower diet contained $6.23 \% \mathrm{CF}$ $(10 \% \mathrm{OK})$ compared to the control diet. Regarding he subsequent effect of dietary fiber through the growing period on feed conversion ratio, there are a significant improve in this trait due to the diet included $4.77 \% \mathrm{CF}$ during the period 6 to 18 weeks of age compared to the control group. 
Table 9. Effect of feeding different levels of dietary crude fiber during growing period on laying performance of local Domiaty ducks during the laying period (24-36 wks.).

\begin{tabular}{|c|c|c|c|c|}
\hline \multirow{2}{*}{ Age (wks.) } & \multicolumn{3}{|c|}{ Dietary fiber level, \% } & \multirow[t]{2}{*}{$\begin{array}{c}\text { Pooled } \\
\text { MSE }\end{array}$} \\
\hline & 3.65 & 4.77 & 6.23 & \\
\hline \multicolumn{5}{|c|}{ Egg number/ duck } \\
\hline $24-28$ & $13.29^{\mathrm{a}}$ & $12.25^{\mathrm{b}}$ & $13.0^{\mathrm{a}}$ & 0.18 \\
\hline $28-32$ & 15.46 & 15.67 & 16.00 & 0.16 \\
\hline $32-36$ & $16.50^{\mathrm{b}}$ & $20.33^{\mathrm{a}}$ & $15.25^{\mathrm{c}}$ & 0.78 \\
\hline $24-36$ & $45.25^{\mathrm{b}}$ & $48.24^{\mathrm{a}}$ & $44.25^{\mathrm{b}}$ & 0.63 \\
\hline \multicolumn{5}{|l|}{ Laying rate, $\%$} \\
\hline $24-28$ & $47.5^{\mathrm{a}}$ & $43.8^{\mathrm{b}}$ & $46.4^{\mathrm{ab}}$ & 0.65 \\
\hline $28-32$ & 55.2 & 56.0 & 57.1 & 0.58 \\
\hline $32-36$ & $58.9^{\mathrm{b}}$ & $72.6^{\mathrm{a}}$ & $54.5^{\mathrm{c}}$ & 2.77 \\
\hline $24-36$ & $53.9^{\mathrm{b}}$ & $57.4^{\mathrm{a}}$ & $52.7^{\mathrm{b}}$ & 0.75 \\
\hline \multicolumn{5}{|l|}{ Egg weight, g } \\
\hline $24-28$ & 59.33 & 58.26 & 58.86 & 0.37 \\
\hline $28-32$ & $64.63^{\mathrm{a}}$ & $62.46^{\mathrm{b}}$ & $62.53^{\mathrm{b}}$ & 0.38 \\
\hline $32-36$ & $68.40^{\mathrm{a}}$ & $67.33^{\mathrm{ab}}$ & $67.07^{\mathrm{b}}$ & 0.26 \\
\hline $24-36$ & 64.08 & 63.88 & 63.25 & 0.17 \\
\hline \multicolumn{5}{|c|}{ Egg mass, g/ duck } \\
\hline $24-28$ & $788.8^{\mathrm{a}}$ & $713.7^{\mathrm{b}}$ & $765.2^{\mathrm{ab}}$ & 13.72 \\
\hline $28-32$ & 999.1 & 978.5 & 1000.5 & 10.50 \\
\hline $32-36$ & $1128.7 \mathrm{~b}$ & $1368.5 \mathrm{a}$ & $1022.7 \mathrm{c}$ & 52.14 \\
\hline $24-36$ & $2899.3 b$ & $3081.8 \mathrm{a}$ & $2798.7 \mathrm{c}$ & 43.12 \\
\hline
\end{tabular}

Subsequent effect to dietary fiber on reproductive traits:

No significant influence due to the previous dietary different levels of CF during the growing period on fertility $\%$, hatchability $\%$ and chick weight at hatch could be detected as shown in Table 10. However, it is noted that total embryonic mortality was decreased as a result from the previous grower diet contained $4.77 \%$ CF by about $9.9 \%$ and there are improvement in hatchability of fertile eggs produced from ducks fed the same diet by about $2.26 \%$ compared to the control diet. Economic efficiency:

It is interesting to note from economical view that the total feed cost/ duck was lower for ducks fed diets contained moderate and high levels of CF than control diet, logically this decrement in feed cost due to decrease the cost of source $\mathrm{CF}$ in diet. The subsequent effect of dietary different levels of $\mathrm{CF}$ on economic efficiency (EE) of egg production clearly observed that no any detrimental effect on EE due to dietary treatments.

Table 10. Effect of feeding different levels of dietary crude fiber during growing period on feed consumption and conversion of local Domiaty ducks during the laying period

\begin{tabular}{lcccc}
\hline \multirow{2}{*}{ Age (wks.) } & \multicolumn{3}{c}{ Dietary fiber level, $\mathbf{\%}$} & Pooled \\
\hline Feed consumption & $\mathbf{3 . 6 5}$ & $\mathbf{4 . 7 7}$ & $\mathbf{6 . 2 3}$ & MSE \\
$24-28$ & 3757.1 & 3790.1 & 3781.2 & 22.14 \\
$28-32$ & 4543.9 & 4562.5 & 4533.6 & 21.59 \\
$32-36$ & $4938.9^{\mathrm{a}}$ & $4870.1^{\text {ab }}$ & $4770.8^{\mathrm{b}}$ & 32.54 \\
$24-36$ & 13239.9 & 13222.7 & 13085.6 & 49.34 \\
Feed conversion ratio & $(\mathbf{g ~ F . / ~} \mathbf{g ~ E M})$ & & \\
$24-28$ & $4.77^{\mathrm{b}}$ & $5.32^{\mathrm{a}}$ & $4.94^{\mathrm{ab}}$ & 0.11 \\
$28-32$ & 4.55 & 4.66 & 4.54 & 0.07 \\
$32-36$ & $4.38^{\mathrm{b}}$ & $3.55^{\mathrm{c}}$ & $4.67^{\mathrm{a}}$ & 0.17 \\
$24-36$ & $4.54^{\mathrm{a}}$ & $4.32^{\mathrm{b}}$ & $4.68^{\mathrm{a}}$ & 0.07
\end{tabular}

a,b,c :means in the same row bearing different superscripts are significantly different $(p \leq 0.05)$.

Table 11. The subsequent effect of feeding different levels of dietary crude fiber during growing period on hatchability traits of local Domiaty ducks

\begin{tabular}{|c|c|c|c|c|}
\hline \multirow{2}{*}{$\begin{array}{l}\text { Parameters, } \\
\%\end{array}$} & \multicolumn{3}{|c|}{ Dietary fiber level, \% } & \multirow[t]{2}{*}{$\begin{array}{c}\text { Pooled } \\
\text { SEM }\end{array}$} \\
\hline & 3.65 & 4.77 & 6.23 & \\
\hline Fertility, \% & 94.9 & 93.3 & 95.2 & 2.08 \\
\hline $\begin{array}{l}\text { Hatchability } \\
\text { of set eggs, \% }\end{array}$ & 75.6 & 76.0 & 75.9 & 4.06 \\
\hline $\begin{array}{l}\text { Hatchability of } \\
\text { fertile eggs, } \%\end{array}$ & 79.7 & 81.5 & 79.7 & 3.62 \\
\hline EEM, \% & $6.4^{\mathrm{ab}}$ & $5.3^{\mathrm{ab}}$ & $3.6^{\mathrm{b}}$ & 2.01 \\
\hline LEM, \% ${ }^{1}$ & $7.7^{\mathrm{ab}}$ & $5.3^{\mathrm{b}}$ & $7.2^{\mathrm{b}}$ & 2.39 \\
\hline Pip dead, \% & $6.2^{\mathrm{b}}$ & $7.9^{\mathrm{ab}}$ & $9.4^{\mathrm{a}}$ & 2.37 \\
\hline Total EM, \% & 20.3 & 18.5 & 20.2 & 3.29 \\
\hline $\begin{array}{l}\text { Chick wt. (g) } \\
\text { at hatch }\end{array}$ & 45.7 & 43.0 & 44.3 & 1.51 \\
\hline
\end{tabular}

Table 12. The subsequent effect of feeding different levels of dietary crude fiber during growing period on economic efficiency of local Domiaty ducks

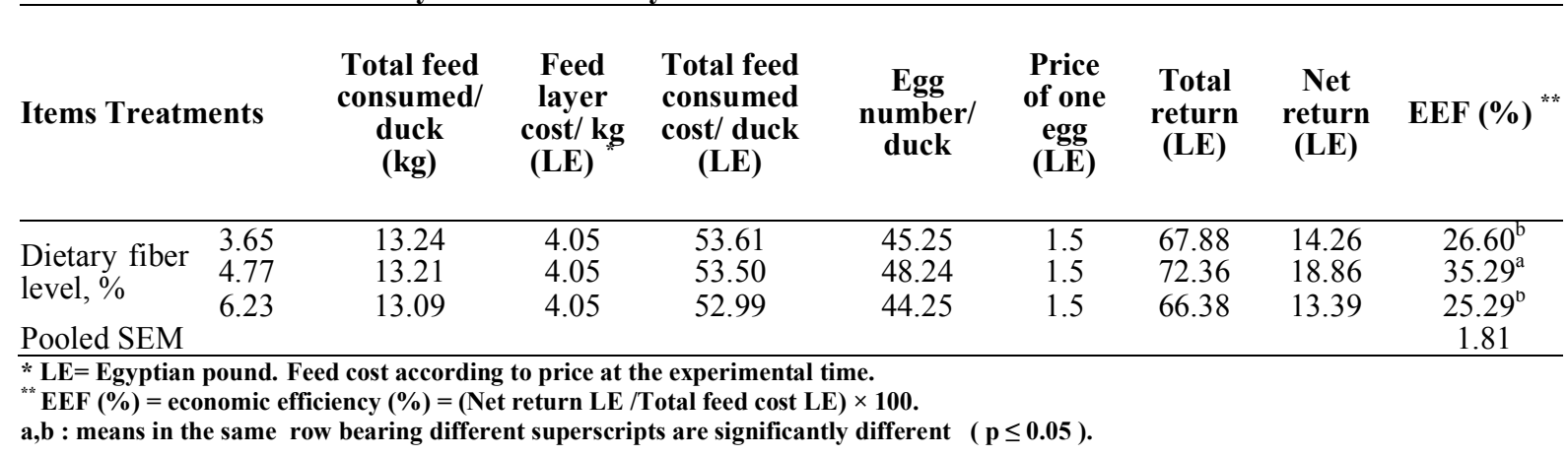




\section{CONCLUSION}

The results in the current study imply an important strategies inclusion moderate amount of $\mathrm{CF}$ in the grower diet for ducks from 6 to 18 weeks of age to decrease the cost of feeding, enhance duck's welfare and without any adverse influence on growth performance and reproductive performance as a subsequent effect. From economic efficiency view, it could be concluded that the grower Domiaty duck's diet which contained $4.77 \%$ CF (diet contained) $5 \%$ OK can be used to maximize productive, reproductive performance and $\mathrm{EE}$ under environmental Egyptian condition.

\section{REFERENCES}

Abbas, A.M.(1992). Effect of dietary fiber on broiler performance. J. of Agric. Sci.(17)(10)3165-3173.

Abdallaha, A,G; M.M. Beshara and Y.S. Rizk (2016). Effect of different levels and sources of dietary fiber on productive and economic performance of local laying hens 2-during laying period. Egypt. Poult. Sci. (36) (I): 97-120.

Abd El-latif, S.A. (2000). Effect of dietary fiber on performance and digestibility of nutrients for growing Pekin ducks. Proc. $3^{\text {rd }}$ All Africa Conf. Anim. Agric. And $11^{\text {th }}$ Conf. Egyptian Soc. Anim. Pro., Alexandria, Egypt, 6-9 November.

Amerah, A. M.; V. Ravindran and R. G. Lentle (2009). Influence of insoluble fibre and whole wheat inclusion on the performance, digestive tract development and ileal microbiota profile of broiler chickens. Br. Poult. Sci. 50:366-375.

Association of Official Analytical Chemists (AOAC) (1990). Official methods of analysis. $13^{\text {th }} \mathrm{Ed}$. Published by the AOAC.,Washington,D.C., USA.

Burhalter, T.M.; N.R. Merchen; L.L. Bauer; S.M. Murray; A.R. Patil; J.L. Brent and G.C. Fahey (2001). The ratio of insoluble to soluble fiber components in soybean hulls affect ileal and total-tract nutrient digestibility and fecal characteristics of dogs. J. Nutr., 131: 1978-1985.

De Blas, J. C.; J. Garcia and R. Carabano (1999). Role of fiber in rabbit diets: A review. Ann. Zootech. (Paris) 48: 3-13.

Duncan, D.B. (1955). Multiple ranges and multiple ftest, Biometries 11: 1-42.

Feed Composition Tables For Animal and Poultry Feedstuffs Used In Egypt, (2001). Technical builetin No, 1, Center Lab Feed and Food; Ministry of Agriculture, Egypt.

Hetland, H. and B. Svihus (2001). Effect of oat hulls on performance, gut capacity and feed passage time in broiler chickens. Br. Poult. Sci. 42:354-361.

Hetland, H.; B. Svihus and M. Choct (2005). Role of insoluble fiber on gizzard activity in layers. Worlds Poultry Science J., 60: 415-422.

Hetland, H. and B. Svihus (2007). Inclusion of dust bathing materials affects nutrient digestion and gut physiology of layers. J. Appl. Poult. Res. 16:22-26.
Feed Composition Tables for Animals and Poultry Feedstuffs Used in Egypt (2001). Technical Bulletin No.,1, Central Lab. For Food and Feeds (CLFF) Ministry of Agric. Res. Cent. Egypt.

Hus,J.C.; L.I. Chen and B. Yu (2000). Effects of levels of crude fiber on growth performance and performance and intestinal carbohydrates of domestic goslings. Asian-Aus J. Anim. Sci. 13 (10) 1450-1454.

González-Alvarado, J. M.; E. Jiménez-Moreno; R. Lázaro and G. G. Mateos (2007). Effects of type of cereal, heat processing of the cereal, and inclusion of fiber in thediet on productive performance and digestive traits of broilers. Poult. Sci. 86:1705-1715.

González-Alvarado, J. M.; E. Jiménez-Moreno; D. G. Valencia; R. Lázaro and G.G. Mateos (2008). Effects of fiber source and heat processing of the cereal on the development and $\mathrm{pH}$ of the gastrointestinal tract of broilers fed diets based on corn or rice. Poult. Sci. 87:1779-1795.

Gonzalez-Alvarado, J.M.; E. Jimenez-Moreno; D. Gonzalez-Sanchez; R. Lazaro and G.G. Mateos (2010). Effect of inclusion of oat hulls and sugar beet pulp in the diet on productive performance and digestive traits of broilers from 1 to 42 days of age. Animal Feed Science and Technology 162:37-46.

Jimenez-Moreno E.; S. Chamorro; M. Frikha; H.M. Safaa; R. Lazaro and G.G. Mateos (2011). Effects of increasing levels of pea hulls in the diet on productive performance, development of the gastrointestinal tract, and nutrient retention of broilers from one to eighteen days of age. Animal Feed Science and Technology, 168, 100-112.

Jorgensen H.; X.Q. Zhao; K.E.B. Knudsen and B.O. Eggum (1996). The influence of dietary fibre source and level on the development of the gastrointestinal tract, digestibility and energy metabolism in broiler chickens. British Poultry Science, 75, 379-395.

Kalmendal, R.; K. Elwinger; L. Holm and R. Tauson (2011). High-fiber sunflower cake affects small intestinal digestion and health in broiler chickens. British Poultry Science 52:86-96.

Liang, Y.; H. Xin; E. F. Wheeler; R. S. Gates; H. Li; J. S. Zajaczkowski; P. A. Topper; K. D. Casey; B. R. Behrends and F. J. Zajaczkowski. (2005). Ammonia emissions from US laying hen houses in Iowa and Pennsylvania. Trans.ASAE48:19271941.

Mailer, R. (2006). Chemistry and quality of olive oil. NSW Deparment of Primary Indutries .WWW. dpi.nsw.gov.au.

Mateos , G.G.; E. Jiménez-Moreno; M.B. Serrano and R.B. Lázaro ( 2012). Poultry response to high levels of dietary fiber sources varying in physical and chemical characteristics. J. appl. Poult. Res. $21: 156-174$. 
NRC (1994). National Research Council. Nutrient Requirement for Poultry. Ninth Revised Ed. National Academy Press, USA.

Perez, V. G.; C. M. Jacobs; J. Barnes; M. C. Jenkins; M. S. Kuhlenschmidt; G. C. Fahey; C. M. Parsons and J. E. Pettigrew (2011). Effect of corn distillers dried grains with solubles and Eimeria acervulina infection on growth performance and the intestinal microbiota of young chicks. Poult. Sci. 90:958-964.

Pottgüter, R. (2009). Rohstoffeinsatz in der Geflügelfütterung - Alternativen zu Mais und Soja. In: Geflügeljahrbuch, 27-36. Ulmer. ISBN 978-3-8001-5771-6.

Roberts, S. A.; H. Xin; B. J. Kerr; J. R. Russell and K. Bregendahl (2007). Effects of dietary fiber and reduced crude protein on ammonia emission from laying-hen manure. Poult. Sci. 86:1625-1632.

Sadeghi1, H.; A. Teimouri Ynsari and Z. AnsariPirsarai (2009). Effects of different olive cake by products on dry matter intake, nutrient digestibility and performance of Zel sheep. Int. J. Agr. Biol., 11: 39-43.

Sklan, D.; A. Smirnov and I. Plavnik (2003). The effect of dietary fiber on the small intestines and apparent digestion in the turkey. Br. Poult. Sci. 44:735-740.

SPSS. (2008). SPSS User's Guide Statistics. Ver. 17. Copyright SPSS Inc., USA.

Svihus, B. ( 2011). The gizzard: function, influence of diet structure and effects on nutrient availability. World's Poultry Sci. J., 67: 207-224.

Siregar A.P.; R.B. Cumming and D.I. Farrell (1982). The nutrition of meat-type ducks. 3. The effects of fiber on biological performance and carcass characteristics. Australian Journal of Agricultural Research, 33, 877-886.
Servili .M.; B. Sordini; S. Esposto; S. Urbani; G. Veneziani; I.D. Maio; R. Selvagginin and A. Taticchi (2014). Biological activities of phenolic compounds of extra vigin olive oil: review. Antioxidants Journal. 3:1-23.

Stark, A.H. and Z. Madar (2002). Olive oil as a functional food: Epidemiology and Nutritional Approaches. Nutrition Reviews. 60:170-176.

Svihus, B. ( 2011). The gizzard: function, influence of diet structure and effects on nutrient availability. World's Poultry Sci. J., 67: 207-224.

Van Krimpen, M. M.; R. P. Kwakkel; C. M. C. van Peet-Schwering; L. A. den Hartog and M. W. A. Verstegen (2009). Effects of nutrient dilution and non-starch polysaccharide concentration in rearing and laying diets on eating behavior and feather damage of rearing and laying hens. Poult. Sci. 88:759-773.

Van Scest, P.J.; J.B. Robertson and A. Lewis (1991). Methods of dietary fiber, neutral detergent fiber and nonstaech polysaccharides in relation to animal nutrition. Journal dairy Science 74:35833597.

Victor P. Lim Jr.; Jayson J. Juan; Oliver F. Celestino; Joice V. San Andres and Ernesto A. Martin (2013). Beneficial effects of insoluble raw fiber concentration to layer diet. Philipp J Vet Anim. Sci., 39 (1): 43-52.

Wang,S.P.; W. J. Wang; D. S. Yang; X. L. Zhao; D. M. Luo and Y. B. Guo (2017). Growth, carcass, and physiological traits of growing male china microducks fed various levels of dietary crude fiber. Czech J. Anim. Sci., 62, (8): 347-356.

Yokhana J.S.; G. Parkinson and T.L. Frankel (2016): Effect of insoluble fiber supplementation applied at different ages on digestive organ weight and digestive enzymes of layer-strain poultry. Poultry Science, 95, 550-559.

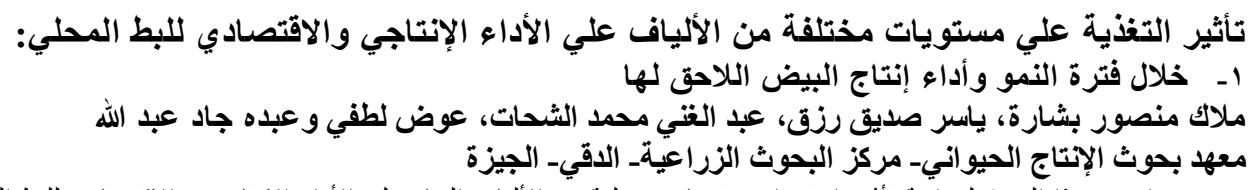

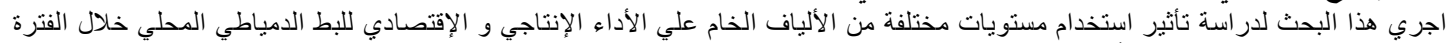

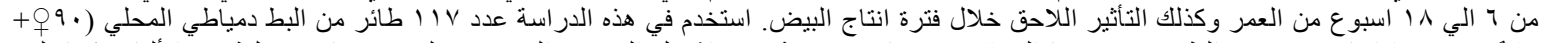

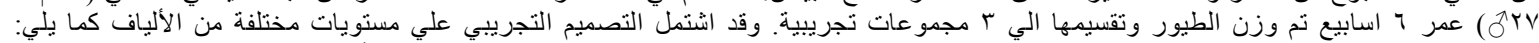

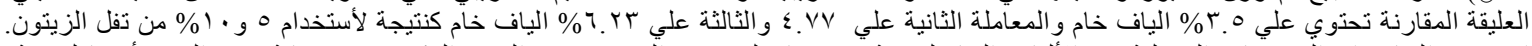

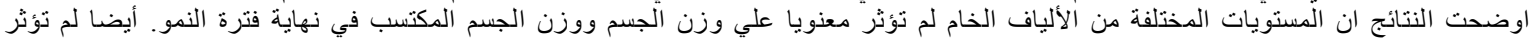

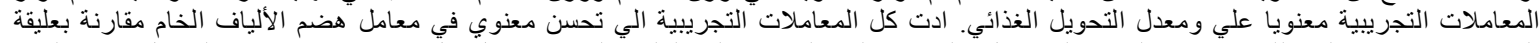

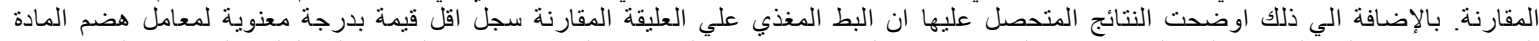

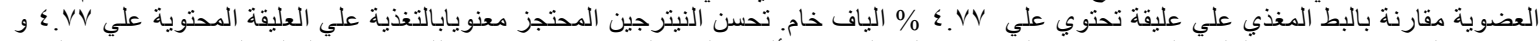

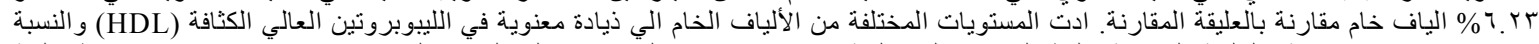

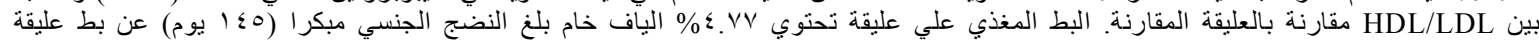

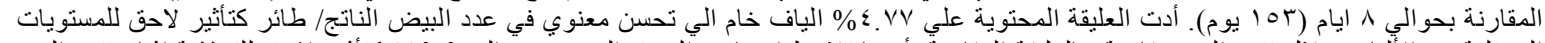

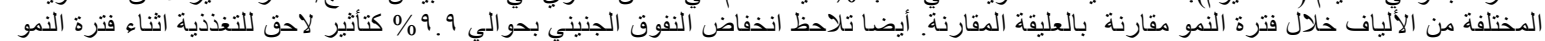

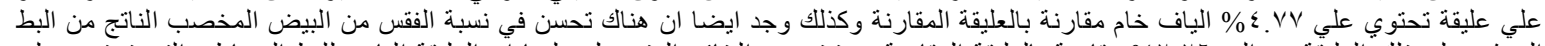

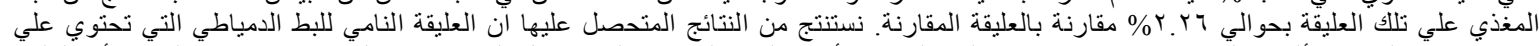

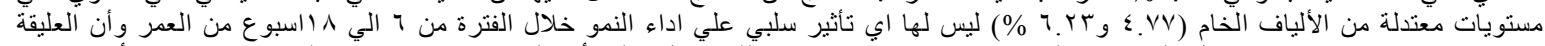

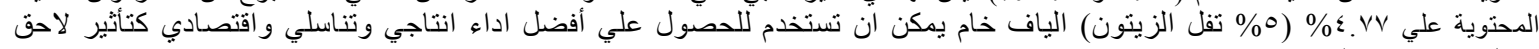
خلال فترة انتاج البيض. 